W P 1015

The Consequences of Banking Crises on Public Debt

Davide Furceri, Aleksandra Zdzienicka

Juin 2010 


\section{GATE Groupe d'Analyse et de Théorie Économique Lyon-St Étienne}

93, chemin des Mouilles 69130 Ecully - France

Tel. +33(0)4 72866060

Fax $+33(0) 472866090$

6, rue Basse des Rives 42023 Saint-Etienne cedex 02 - France

Tel. +33 (0)4 77421960

Fax. $+33(0) 477421950$

Messagerie électronique / Email : gate@gate.cnrs.fr

Téléchargement / Download : http://www.gate.cnrs.fr - Publications / Working Papers 


\title{
The Consequences of Banking Crises for Public Debt ${ }^{1}$
}

\author{
Davide Furceri
}

$O E C D^{r}$

Aleksandra Zdzienicka

GATE-CNRS, University of Lyon ${ }^{\infty}$

\begin{abstract}
The aim of this paper is to assess the consequences of banking crises for public debt. Using an unbalanced panel of 154 countries from 1980 to 2006, the paper shows that banking crises are associated with a significant and longlasting increase in government debt. The effect is a function of the severity of the crisis. In particular, we find that for severe crises, comparable to the most recent one in terms of output losses, banking crises are followed by a medium-term increase of about 37 percentage points in the government gross debt-to-GDP ratio. We also find that the debt ratio increased more in countries with a worse initial fiscal position (in terms of the gross debt-to-GDP ratio) and with a higher share of foreign debt.
\end{abstract}

Keywords: Output Growth, Financial Crisis, CEECs.

JEL: G1, E6

\footnotetext{
${ }^{1}$ We would like to thank Christophe André, Jorgen Elmeskov, Balász Egert, Sebastian Schich, Jean-Luc Schneider and David Turner for helpful comments on an earlier draft, and Carlo Cottarelli and the other participants to the Banca d'Italia $12^{\text {th }}$ Public Finance Workshop for useful discussions and suggestions. The views expressed in this paper are those of the authors and do not necessarily represent those of the OECD or its member countries.

${ }^{\Upsilon}$ Mailing address: OECD, 2 rue André-Pascal, 75775 Paris CEDEX 16, Email: davide.furceri@oecd.org.

${ }^{\infty}$ Mailing address: University of Lyon, Lyon, F-69003, France; CNRS, UMR 5824, GATE, Ecully, F-69130, Email: azdzieni@ens-lsh.fr.
} 


\section{Introduction}

Financial crises are not only typically associated with sharp economic downturns ${ }^{2}$, but also with a substantial deterioration of fiscal positions. Declining revenues due to weaker economic conditions, higher expenditures associated with bailout costs and demand stimuli have historically led to a rapid deterioration of fiscal balances and increase of public debt. ${ }^{3}$

Analysing a panel of developed and developing economies, Reinhart and Rogoff (2009) estimate that in the 3 years after the occurrence of a banking crisis the real value of government debt rose on average by 86 percent. However, arguably measuring the change in debt this way can be misleading because it depends on the initial level of the debt. Alternatively, if the rise in debt is measured in terms of the change in the ratio of debt to GDP, the figures becomes considerably smaller; using similar episodes to those chosen by Reinhart and Rogoff (2009), but focusing on the percentage point increase of the debt-to-GDP ratio, the historical average cumulative increase in the debt-GDP ratio 3 years after the occurrence of banking crises is about 9 percentage points of GDP (Figure 1). The effect varies considerably across the episodes presented in the figure, ranging from an almost insignificant increase in the case of Thailand in 1997 to an increase of more than 35 percentage points for Finland in 1991. In addition, countries differ not only in terms of the magnitude of the impact in the 3 years following the crisis, but also in terms of the dynamic of the response and in terms of medium-term effects. For example, three years after financial crises in Japan and Finland the effect on debt is very similar, however the medium-term evolution beyond three years is very different (Figure 2).

\footnotetext{
${ }^{2}$ See, for example, Aziz et al. (2000), Barro (2001), Hutchinson and Ilan (2005), Boyd et al. (2005), Cerra and Saxena (2008), Furceri and Mourougane (2009a,b) Furceri and Zdzienicka (2010a,b).

${ }^{3}$ See, for example, Caprio and Klingebiel (1997), Honohan and Klingebiel (2000), Laeven and Valencia (2008a), Reinhart and Rogoff (2008), Furceri and Mourougane (2009a), OECD (2009).
} 
The current financial crisis is exceptional not only for its severity and its synchronicity across countries, but also for the policy response: monetary policy rates have been slashed, central bank balance sheets expanded, and most governments have taken expansive fiscal measures to counter the economic downturn. For many countries debt levels are projected to increase substantially. For example, in OECD countries (Figure 3) gross government debt-toGDP ratios are projected to increase by more than 20 percentage points by 2011 , and in some cases (Iceland, Ireland, Japan, and the United Kingdom) by more than 30 percentage points (OECD, 2010). Focusing on a longer time horizon (Figure 4), debt levels may increase even more $(O E C D, 2010)$. Based on the assumption that government consolidation measures are only gradual but sufficient to stabilise debt-to-GDP ratios over the long term, debt-GDP ratios may still increase by about 30 percentage points by 2025 compared to pre-crisis level, with the largest increase being projected for Ireland (about 100 percentage points) and the United Kingdom (about 80 percentage points). ${ }^{4}$

In the context of the aftermath of the recent financial crisis this paper considers past historical episodes to examine what has happened to public debt over the medium and long term, The paper provides estimates of the dynamic impact that banking crises episodes have typically had on the gross debt-to-GDP ratio, and of the role that structural and policy variables have had in shaping this response. The analysis complements previous work analysing the fiscal costs associated with banking crises in several respects by:

- Focusing on gross public debt as a dependent variable. Several papers in the literature have instead focused on trying to estimate only the bailout costs

\footnotetext{
${ }^{4}$ In particular, it is assumed that the underlying primary fiscal balance improves by $1 / 2$ per cent of GDP until it is sufficient to ensure that the debt-to-GDP ratio is stable. See, Chapter 4 of OECD Economic Outlook 87 (2010) for more details.
} 
associated with banking crises. ${ }^{5}$ However, there are two main problems with this approach. First, estimates of fiscal bailouts depend markedly on the methodology used. As a result, the difference in the estimates across studies focusing on the same episodes is large (Frydl, 1999 and Vale, 2006). Second, bailout costs are only a part of the fiscal cost associated with banking crises. In fact, the fiscal consequences of banking crises also result from the reduced revenues associated with output losses, the increase in spending due to automatic stabilisers and from discretionary increases in the public deficit.

- The focus is on the debt-to-GDP ratio rather than the percentage change in debt levels. This is important for two reasons. First, the debt-to-GDP ratio is a better measure to assess fiscal sustainability. Second, analysing the percentage increase of debt levels in the aftermath of banking crises could lead to possible misinterpretations since the percentage increase crucially depends on the initial level of the debt before the occurrence of the crisis. For example, consider two crises episodes: Sweden (1991) and Colombia (1998). Following Reinhart and Rogoff (2009), the increase in the gross public debt in the three years following the banking crisis as in Colombia implies that public debt increased by about 175 percent while in Sweden it increased by about 60 percent. However, when the percentage point increase in the debt-to-GDP ratio is considered, as in Figure 1, the result leads to a spectacular reversal of this ranking: fiscal positions deteriorated significantly more in Sweden (27 percentage points of GDP) than in Colombia (13 percentage points of GDP).

\footnotetext{
${ }^{5}$ See among others Caprio et al. (2005), and Sanhueza (2001).
} 
- Presenting inferential empirical evidence on the increase of the debt-to-GDP ratio in the aftermath of banking crises. The only work, to our knowledge, that tries to assess the increase in public debt (not as ratio to GDP, as discussed previously) is Reinhart and Rogoff (2009). However, in their paper, the authors present only descriptive evidence of the increase in the gross government debt 3 years after the occurrence of banking crises, without controlling for countries characteristics and other factors that could explain the increase in public debt in the short term and different responses across countries.

- Estimating the effect of banking crises on the debt-to-GDP ratio both in the short and in the long-run, ${ }^{6}$ in particular to assess whether fiscal costs associated with the crises have been permanent or if they have tended to dissipate in the long term.

- Analysing the heterogeneity of responses among different countries and episodes.

Using an unbalanced panel of 154 countries from 1970 to 2006, the main findings of the paper is to show that banking crises are associated with a significant and long-lasting increase in the government debt-to-GDP ratio. The magnitude of effect is a function of the severity of the crisis. In particular, we find that for severe crises, comparable to the most recent one in terms of output loss, banking crises are on average followed by a medium-term increase of about 37 percentage points in the government gross debt-to-GDP ratio. We also find that larger increases in debt tended to occur in those countries with the worse initial fiscal positions (in terms of gross debt-to-GDP ratio) and with the highest share of foreign public debt.

\footnotetext{
${ }^{6}$ Previous works generally focus on a time horizon of 3 years.
} 
The rest of the paper is organised as follows: the next section describes the data and the empirical methodology used to examine the effects of a financial crisis on debt; section three describes the results; and finally, section four concludes with the main findings.

\section{Data and Empirical Methodology}

\subsection{Data}

Data for real gross debt-to-GDP ratio are taken from the IMF World Economic Outlook (2009). Data for the share of gross foreign public debt over total public debt are taken from Panizza (2008), where public foreign debt is defined as issued in foreign countries and under the jurisdiction of a foreign court. Data for banking crises episodes are taken from Laeven and Valencia (2008a). In the latter paper the authors provide detailed information on the starting date of several banking, currency and debt crises. The dataset is constructed by combining quantitative indicators measuring banking sector distress, such as a sharp increase in nonperforming loans and bank runs, with a subjective assessment of the situation. In particular, the database extends and builds on the database of Caprio, et al. (2005) and covers the universe of systemic banking crises (124 episodes) for the period 1970-2007. ${ }^{7}$

\subsection{Empirical Methodology}

In order to estimate the dynamic impact of banking crises episodes on the debt-to-GDP ratio the paper follows the approach proposed by Jorda (2005) and Teulings and Zubanov (2009) which consists of estimating impulse response functions (IRFs) directly from local projections. In detail, for each future period $k$ the following equation has been estimated on annual data:

$$
b i, t+k-b i, t=\alpha i k+j=1 l \gamma j k \Delta b i, t-j+\beta k D i, t+\varepsilon i, t k
$$

\footnotetext{
${ }^{7}$ See Tables A1 and A2 for a detailed description of crises episodes.
} 
with $k=1, . .8$. Where $b$ indicates the government gross debt-to-GDP ratio, $D$ is a dummy that takes the value equal to 1 in the occurrence of a banking crisis and zero otherwise, $\alpha i$ represent country fixed effects, $\gamma j$ captures the persistence in changes of the debt ratio, and $\beta k$ measures the impact of banking crises on the change of the debt ratio for each future period $k$. The number of lags $(l)$ has been tested, and the results suggest that inclusion of two lags produce the best specification. ${ }^{8}$ Correction for heteroskedasticity, when appropriate, are applied using White robust standard errors, while the problem of autocorrelation in the errors is addressed using two lags of the explanatory variable as regressors. ${ }^{9}$ Impulse response functions (IRFs) are then obtained by plotting the estimated coefficients $\beta k$ for $k=1, . .8$.

An alternative way of estimating the dynamic impact of banking crises on output is to estimate an ARDL equation of debt-to-GDP ratio and crises dummies and to compute IRFs from the estimated coefficients. ${ }^{10}$ However, the IRFs derived using this approach are sensitive to the choice of the number of lags, and the inclusion of interaction terms in the equation often leads to problems of multicollinearity, thus making the IRFs unstable. In addition, the significance of long-lasting effects on the debt ratio with ARDL models can be simply driven by the use of onetype shock models (Cai and Den Haan, 2009).

In contrast, the approach used in this paper does not suffer from these problems because the lags of the change in the debt ratio enter only as control variables and are not used to derive the IRFs. Finally, the confidence bands associated with the estimated IRFs are easily computed

\footnotetext{
${ }^{8}$ The results are extremely robust to the number of lags included in the specification.

9 Tests for autocorrelation of the residuals have been carried out and have rejected the hypothesis of serial correlation.

${ }^{10}$ This approach was initially proposed by Romer and Romer (1989) and then recently applied by Cerra and Saxena (2008), Furceri and Mourougane (2009a,b) and Furceri and Zdzienicka (2010b) to assess the impact of financial crises on economic activity.
} 
using the standard deviations of the estimated coefficients $\beta k$, and Monte-Carlo simulations are not required.

\section{Results}

\subsection{Baseline}

The impact of banking crises on the gross government debt-to-GDP ratio is estimated as described in equation (1). The results for each period $k$ are displayed in Figure 5, together with the associated confidence bands. ${ }^{11}$ Looking at the figure it is immediately apparent that banking crises are associated with a significant and long-lasting increase in public debt. In particular, banking crises have typically increased the government gross debt-to-GDP ratio by about 12 percentage points in the short term (1 year after the occurrence of the crisis), and by about 10 percentage points in the medium term ( 8 years after). In addition, we find that the largest increase in the debt ratio (17 percentage points) has typically occurred around 3 years following the occurrence of a banking crisis.

To check for the robustness of the results, equation (1) is re-estimated by alternatively including 1) time fixed effects, 2) a common time trend, 2) a country-specific time trend. Time fixed effects are included to control for specific time shocks, such as those affecting world interest rates. A time trend is used to control for common trends in the developments of debt-toGDP ratios. Finally, a country-specific time trend is included to allow the trend in debt-to-GDP ratio to differ across countries. The results using these different controls remain statistically significant and broadly unchanged (Figure 6a-6c).

\footnotetext{
${ }^{11}$ See Table A3 for more detailed information regarding the estimated parameters in equation (1).
} 
As an additional robustness test the estimation sample is restricted to those countries for which data for $b i, t+k$ are available for each period $k$. The reason for doing so is to control for a possible composition bias deriving from estimating $b i, t+k$ over an unbalanced set of countries. The results for the restricted sample (displayed in Figure 6d) suggest that the short and the medium term effects are almost identical to those estimated for the unbalanced baseline sample.

Finally, to also test whether the effect is similar between advanced and less developed economies, equation (1) is augmented by including a dummy for OECD countries as a control and as interaction term with the crisis dummy, as follows:

$$
b i, t+k-b i, t=\alpha i k+j=1 l \gamma j k b y i, t-j+\beta k D i, t+\boldsymbol{\vartheta} k O E C D i, t+\delta k O E C D i t D i, t+\varepsilon i, t k
$$

The coefficient associated with the interaction term is statistically significant, suggesting that the effect of banking crises on public debt is not statistically difference between the two groups of countries. The unconditional effect is still positive, statistically significant and of the same order of magnitude as the one estimated in the baseline specification (Table A3).

\subsection{Severity of the crises}

The results presented so far have shown that on average banking crises have had significant and persistent effects on the government debt-to-GDP ratio. However, it is reasonable to think that fiscal policy responses, both in terms of size of fiscal stimulus packages to counter the crisis and in terms of the increase in the deficit due to automatic stabilisers, may be a function of the output losses and therefore vary with the severity of the crisis. This would imply that the baseline estimates tend to over-estimate the impact on government debt for "moderate" banking crises and to under-estimate the impact for "severe" crises. 
To test for this hypothesis equation (1) is for two groups of crises: i) severe crises, i.e. banking crises associated with cumulative output losses (computed as the deviation of the annual growth rate from the average trend) above 4 percent, which are comparable to the current circumstances $^{12}$; ii) moderate crises, i.e. banking crises associated with output losses below 4 percent. The results of this exercise are reported in Figure 7. Looking at the figure it is possible to observe a different response of the debt-to-GDP ratio between moderate and severe crises, both in the short and in the medium term. In particular, for moderate crises (Panel A) the maximum effect is about 15 percentage points after 4 years and it becomes insignificant in the medium term (after 8 years). For severe crises (Panel B-C), the peak effect is about 50 percentage points (three times bigger than the average effect presented in the baseline scenario) and the medium term effect (eight years after) is about 37 percentage points.

The results for severe crises are in line with the recent IMF World Economic Outlook (2010) and OECD Economic Outlook (2010) medium term projections for the debt-to-GDP ratio.

\subsection{Initial Debt}

The rise in public debt in the aftermath of a banking crisis may be more important for countries that had at the time of the crisis a higher initial debt-to-GDP ratio. This hypothesis can be explained by the fact that a higher initial level of debt affects the debt accumulation through debt service. ${ }^{13}$ In times of crisis, debt service burdens increase due to reduced government

\footnotetext{
${ }^{12}$ Output losses are computed as the deviation of the annual growth rate compared to the trend (approximated by the average of annual growth rates over time). The results are qualitatively unchanged for reasonable changes in the threshold value. This is conceptually similar to the cumulative (negative) output gap following a downturn.

${ }^{13}$ See Figure A1 and A2 for the estimated impact of banking crises on government debt service.
} 
revenues and increased risk premia. This last factor tends to be generally more important for countries with a higher initial level of public debt. ${ }^{14}$

To assess the impact of the initial debt-to-GDP ratio on shaping the dynamic response of the government debt-to GDP ratio to banking crises, equation (1) is augmented by including the initial debt-ratio as a control variable and as an interaction term with the crises dummy:

$b i, t+k-b i, t=\alpha i k+j=1 l \gamma j k b y i, t-j+\beta k D i, t+\boldsymbol{\vartheta} k X i, t+\delta k b i, t-b D i, t+\varepsilon i, t k$

The interaction term $b i, t-b D i, t$ is centred on the (over-time and cross-country) mean to make the interpretation of unconditional effects easier. Based on equation (2), for each period $k$, the impact of banking crises on the debt-to-GDP ratio is measured by $\beta k+\delta k b i, t-b$. This implies that the effect will increase as a function of the initial debt ratio if $\delta k>0$.

The results reported in Figure 8 tend to confirm the hypothesis that in countries with larger initial level of debt-to-GDP ratio (corresponding to the $3^{\text {rd }}$ quartile of the distribution, i.e. above 76 percent) the increase in the debt-to-GDP ratio, both in the short ( 1 and 2 years after) and in the medium term ( 8 years after), is about 15 percentage points higher than in countries with lower initial debt (the $1^{\text {st }}$ quartile, i.e. below 20 percent).

\subsection{Foreign Public Debt}

Another factor that may affect the pattern of the public debt-to-GDP ratio in the aftermath of banking crises is the ratio of public foreign debt to total public debt (public foreign debt ratio). First, countries with an high share of foreign public debt may face higher interest payments on

\footnotetext{
${ }^{14}$ See for example Haugh et al. (2009), Schuknecht et al. (2009), Codogno et al. (2003), Gale and Orzag (2003), Gomez-Puig (2006), Manganelli and Wolswijk (2007).
} 
debt coming due as capital markets become unwilling to continue rolling debt over. Second, when foreign exposure is heavy, expectations that debt might not be repaid in the case of depreciation may lead to a self-fulfilling liquidity crunch, and eventually to public debt default. Third, in countries with a high foreign public debt ratio currency depreciation may lead to a substantial increase in the debt burden because of the original sin and lead to debt crises (Flandreau, 2003; Bordo, 2006; Bordo and Meisser, 2006). Fourth, a high level of foreign public debt may lead to significant output losses, especially in emerging economies, since sudden stops or reversals in capital inflows are more likely. ${ }^{15}$

An approach to test whether countries with a higher foreign public debt ratio have been characterised by an higher rise in the debt-to-GDP ratio in the aftermath of banking crises is to re-estimate equation (2) using the initial level of the foreign public debt ratio as control and interaction term with the banking crises dummy. However, a problem with this approach in this case is that the probability of banking crises is endogenous to the share of foreign public debt. ${ }^{16}$

A way to mitigate this problem is to estimate our baseline equation for different levels of the foreign public debt ratio. For simplicity, and homogeneity with the rest of the results presented, we estimate equation (1) for three groups of countries (observations): i) those with a foreign debt ratio lower than the first quartile of the distribution, i.e. below 34 percent (low foreign debt ratio); ii) those with a foreign debt ratio higher than the third quartile of the distribution, i.e. above 83 percent (high foreign debt ratio); iii) those with a foreign debt between the first and the third quartile (average foreign debt ratio). The IRFs corresponding to the three groups are displayed in Figure 9. The results suggest that the public debt-to-GDP ratio increased

\footnotetext{
${ }^{15}$ See, for example, Calvo et al. (2004), Bordo et al. (2008).

${ }^{16}$ Bordo and Meisser (2006) find that, especially if mis-managed, foreign debt can significantly increase the probability of financial crises.
} 
more in those countries with a higher share of foreign debt. In particular, in countries with low foreign debt ratio the increase in the debt ratio is not statically significant different from zero. In countries with average foreign debt ratio, the results point to a long term increase of the debt ratio of about 10 percentage points (which is similar to the baseline effect presented in Figure 5). Finally, in countries with high foreign debt ratio the peak effect is close to 30 percentage points, while the long-term effect is about 20 percentage points. ${ }^{17}$

\section{Conclusions}

Financial crises are typically associated with sharp economic downturns but also with a substantial deterioration of fiscal positions. Declining revenues due to weaker economic conditions, higher expenditures associated with bailout costs and demand stimuli have historically led to a rapid deterioration of fiscal balances and increase of public debt. Focusing on the debt-to-GDP ratio and several episodes of banking crises from 1980 to 2006 this paper aims to quantify the evolution of the government gross debt-to-GDP ratio in the aftermath of banking crises. In particular, using a sample of 154 countries the paper estimates impulse response functions of public debt to banking crises.

The results of this exercise suggest that banking crises have produced a significant and long-lasting increase in the government debt-to-GDP ratio, with the effect being a function of the severity of the crisis. In particular, for severe crises, comparable to the current one in terms of output losses, we find that government debt-to-GDP ratios increased up to 50 percentage points

\footnotetext{
${ }^{17}$ The results obtained by estimating equation (2), using the initial level of the foreign debt ratio as control and interaction term with the banking crises dummy, broadly confirm these results.
} 
at the peak, and by 37 percentage points in the medium term (eight years after the crises onset). The effect is considerably lower for moderate crises.

We also find that the increase in public debt in the aftermath of banking crises depends not only on the severity of the crises but also on countries heterogeneity. In particular, analysing a set of structural and policy variables we find that larger increases in debt occurred in countries with worse initial fiscal positions (in terms of debt-to-GDP ratio) and with a larger share of foreign debt.

Summarising, the results of the paper suggest that financial crisis have a significant and long-lasting impact on public debt. This implies that, given the unprecedented severity of the current financial crisis and the associated fiscal policy response, countries urge to take current and further actions in order to avoid temporary stimuli to increase permanently debt levels, thus putting debt sustainability at risk. 


\section{References}

Aziz, J., Caramazza, F. and R. Salgado, (2000). "Currency crises: In Search of Common Elements," IMF Working Paper 67.

Barro, R. J., (2001). "Economic Growth in East Asia Before and After the Financial Crisis," NBER Working Paper 8330.

Bordo, M.D., (2006). "Sudden Stops, Financial Crises and Original Sin in Emerging Economies: Déjà vu? Global Imbalances and Risk Management: Has the Center become the Periphery", NBER Working Paper, No. W12393.

Bordo, M.D., A. Cavallo and Ch. M. Meissner, (2008). "Sudden Stops: Determinants and Output Effects in the First Era of Globalization, 1880-1913" manuscript UC Davis.

Bordo, M. D. and Ch.M. Meissner, (2006). "The Role of Foreign Currency Debt in Financial Crises: $1880-1913$ vs. 1972-1997"

.Journal of Banking and Finance 60 pp. 3299-3329.

Boyd, J., Kwak, S. and B. Smith, (2005). "The Real Output Loss Associated with Modern Banking Crises", Journal of Money, Credit and Banking, 37, 977-999.

Cai, X. and W.J. Den Haan, (2009). Predicting recoveries and the importance of using enough information, CEPR Working Paper 7508.

Calvo, G. A., A. Izquierdo and L.-F. Mejia, (2004). "On the Empirics of Sudden Stops: The Relevance of Balance-Sheet Effects", NBER Working Paper, No. 10520.

Caprio, G. Jr, and D. Klingebiel, (1997). "Bank Insolvency: Bad Luck, Bad Policy, or Bad Banking?" In Annual World Bank Conference on Development Economics, edited by Michael Bruno and Boris Pleskovic, Washington, DC: The World Bank.

Caprio, Gerard and Daniela Klingebiel, Luc Laeven and Guillermo Noguera, "Banking Crisis Database," In Patrick Honohan and Luc Laeven (eds.), Systemic Financial Crises, Cambridge: Cambridge University Press, 2005.

Cerra. V. and S.C. Saxena, (2008). "Growth Dynamics: The Myth of Economic Recovery", American Economic Review, 98, 439-457

Codogno, L., C. Favero and A. Missale, (2003). "Yield spreads on EMU government bonds", Economic Policy 18, 503-532.

Deatragiache, E. and G. Ho, (2010). "Responding to Banking Crises: Lessons from CrossCountry Evidence", IMF Working Paper 10/18. 
Flandreau, M., (2003). "Crises and punishment: moral hazard and the pre-1914 international financial architecture" in Marc Flandreau ed. Money Doctors: The Experience of International Financial Advising, 1850-2000. London: Routledge.

Furceri D. and A. Mourougane, (2009a). "Financial Crises: Past Lessons and Policy Implications", OECD Economics Department Working Paper 668.

Furceri D. and A. Mourougane, (2009b). "The Effect of Financial Crises on Potential Output: New Empirical Evidence From OECD Countries", OECD Economics Department Working Paper 699.

Furceri, D. and A. Zdzienicka, (2010a). "Banking Crises and Short and Medium Term Output Losses in Developing Countries: The Role of Structural and Policy Variables", World Development, (forthcoming).

Furceri, D. and A. Zdzienicka, (2010b). "The Real Effect of Financial Crises in the European Transition Economies", The Economics of Transition, (forthcoming).

Frydl, E. J., (1999).“The Length and Cost of Banking Crises”, IMF Working Paper WP/99/30.

Gale, W.G. and P. Orszag, (2003). "Economic Effects of Sustained budget Deficits", National Tax Journal, Vol. LVI, No.3.

Gómez-Puig, M., (2006). "Size matters for Liquidity: Evidence from EMU Sovereign Yield Spreads", Economic Letters 90, pages 156-162.

Haugh, D., P. Ollivaud and D. Turner, (2009). "What Drives Sovereign Risk Premiums?: An Analysis of Recent Evidence from the Euro Area", OECD Economics Department Working Paper 718.

Honohan, P. and D. Klingebiel, (2000). “Deposit Insurance: Design and Implementation”, World Bank Working Paper.

Hutchison, M. and N. Ilan, (2005). "How bad are twins? Output costs of currency and banking crises", Journal of Money, Credit and Banking, 37(4),pp. 725-752.

IMF World Economic Outlook 2010.

Jorda, O., (2005). "Estimation and inference of impulse responses by local projections", American Economic Review, vol. 95, no. 1, pp. 161-82.

Laeven, L. and F. Valencia, (2008a). "Systemic banking crises: a new database", IMF Working Paper, WP/08/224.

Laeven L. and F. Valencia, (2008b). "The use of blanket guarantees in banking crises", IMF Working Paper, WP/08/250. 
Manganelli, S. and G. Wolswijk, (2007). "Market Discipline, Financial Integration and Fiscal Rules: What Drives Spreads in the Euro Area Government Bond Market?", European Central Bank Working Papers, No. 745.

OECD Economic Outlook, 85 (2009).

OECD Economic Outlook, 87 (2010).

Panizza, U. (2008). "Domestic and External Public Debt in Developing Countries" UNCTAD Working Paper, 3.

Reinhart, C.M. and K. Rogoff, (2008). "This Time is Different: A Panoramic View of Eight Centuries of Financial Crises", NBER Working Paper, 13882.

Reinhart, C.M. and K. Rogoff, (2009)." The Aftermath of Financial Crises", American Economic Review, 99(2), 466-72.

Romer, C. and D. Romer, (1989). "Does Monetary Policy Matter? A New Test in the Spirit of Friedman and Schwartz", NBER Macroeconomics Annual, 4: 121-170.

Sanhueza, G., (2001). "Chilean Banking Crisis of the 1980s: Solutions and Estimation of the Costs", Central Bank of Chile Working Paper 104.

Schuknecht, L., J. von Hagen and G. Wolswijk, (2009), "Government Risk Premiums in the Bond Market: EMU and Canada", European Journal of Political Economy 25 (3), 371-384.

Teulings, C.N., and N. Zubanov, (2009). "Economic recovery a myth? Robust estimation of impulse responses", CPB Discussion Papers, November, 131.

Vale, B.,(2006). “The Norwegian Banking Crisis”, Norges Bank Occasional Paper No 33.

Figure 1. Cumulative increase in the debt-to-GDP ratio in the three years following the banking crises 
$\%$ points of GDP

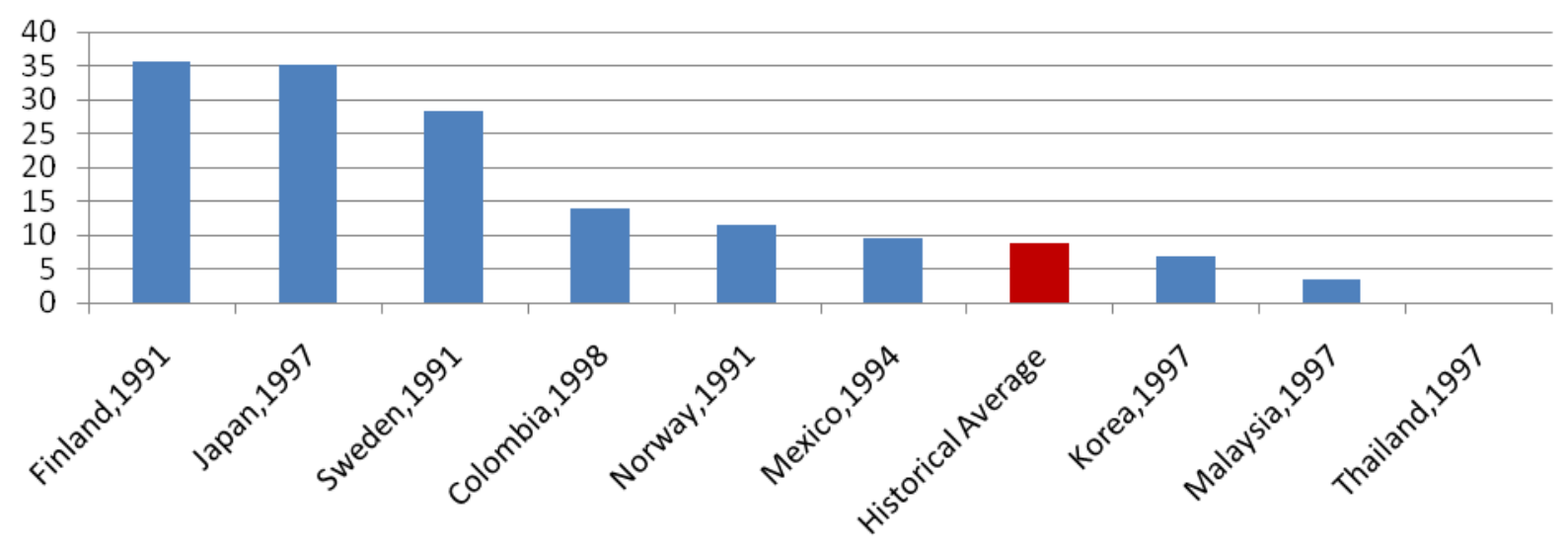

Figure 2. Evolution of the debt-to-GDP ratio following banking crises in Finland and Japan $\%$ points of GDP

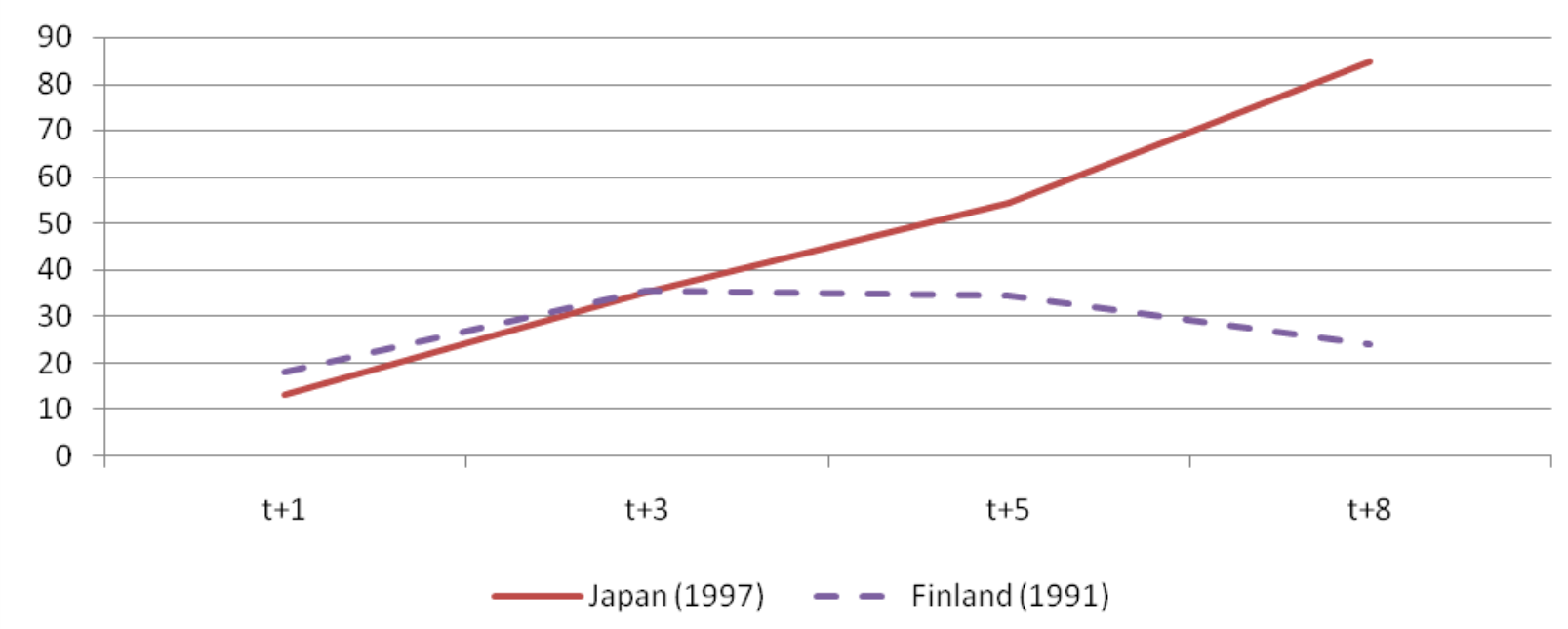

Figure 3. Projected increase in the government debt-to-GDP ratio Period 2007-2011, \% points of GDP 


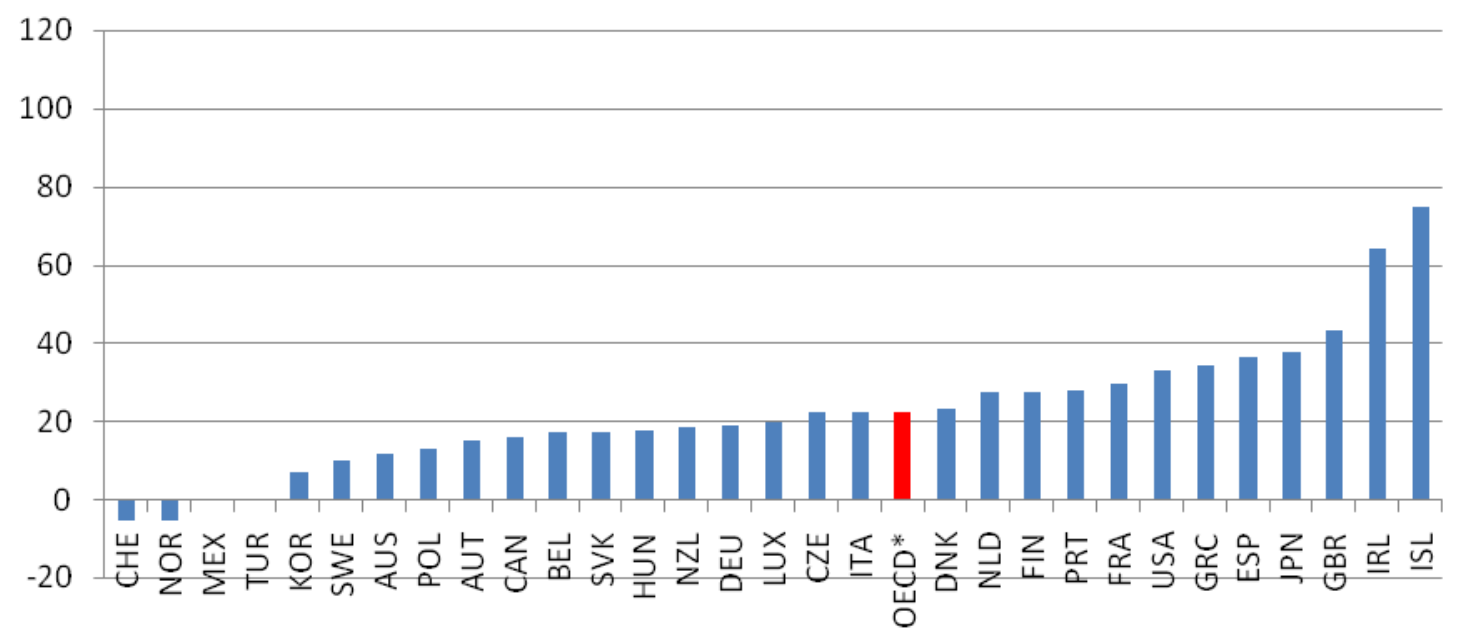

Source: OECD Economic Outlook 87 Database (2010).

Note: * unweighted average of OECD countries excluding Mexico and Turkey.

Figure 4. Projected increase in the government debt-to-GDP ratio

Period 2008- 2025, \% points of GDP

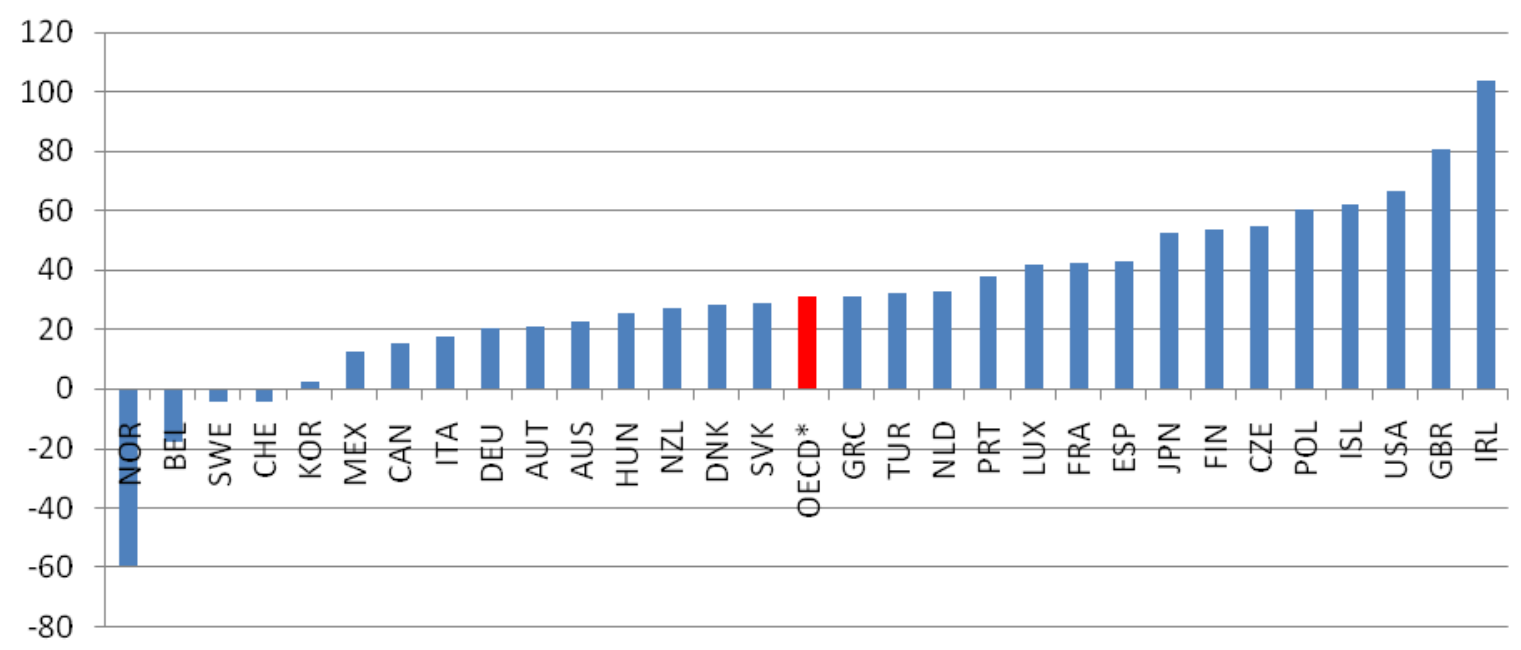

Source: OECD Economic Outlook 87 Database (2010).

Note: * unweighted average of OECD countries excluding Mexico and Turkey. Projections are based on the assumption that government debt-to-GDP will stabilize by 2025 as a result of gradual consolidation measures. See the OECD Economic Outlook 87 (2010) for more details.

Figure 5. The effect of banking crises on the debt-to-GDP ratio

(\% points of GDP) 


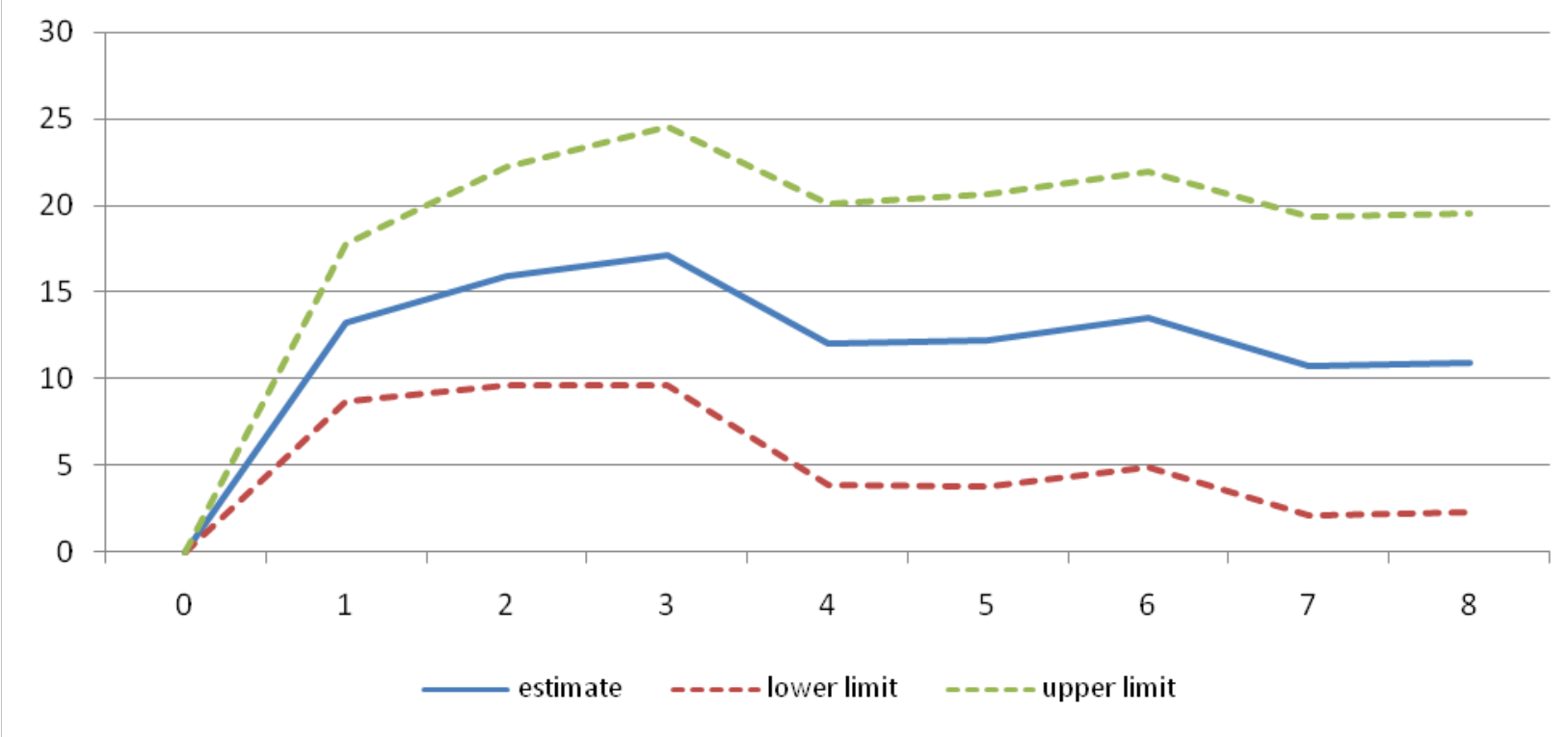

Note: dotted lines represent $90 \%$ confidence bands.

Figure 6. Robustness tests 
(\% points of GDP)

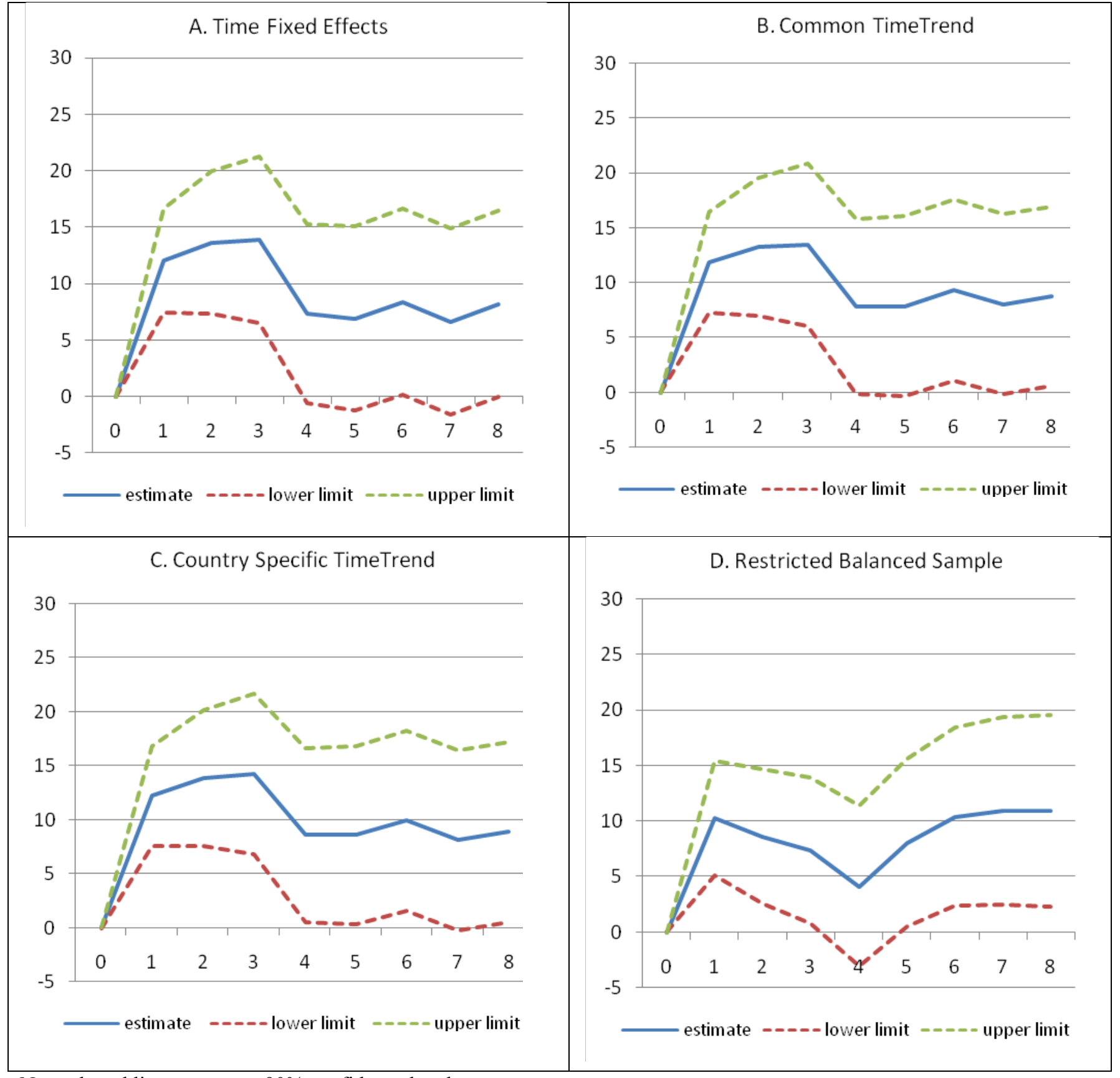

Note: dotted lines represent $90 \%$ confidence bands.

Figure 7. The effect of moderate and severe banking crises on the debt-to-GDP ratio 
(\% points of GDP)
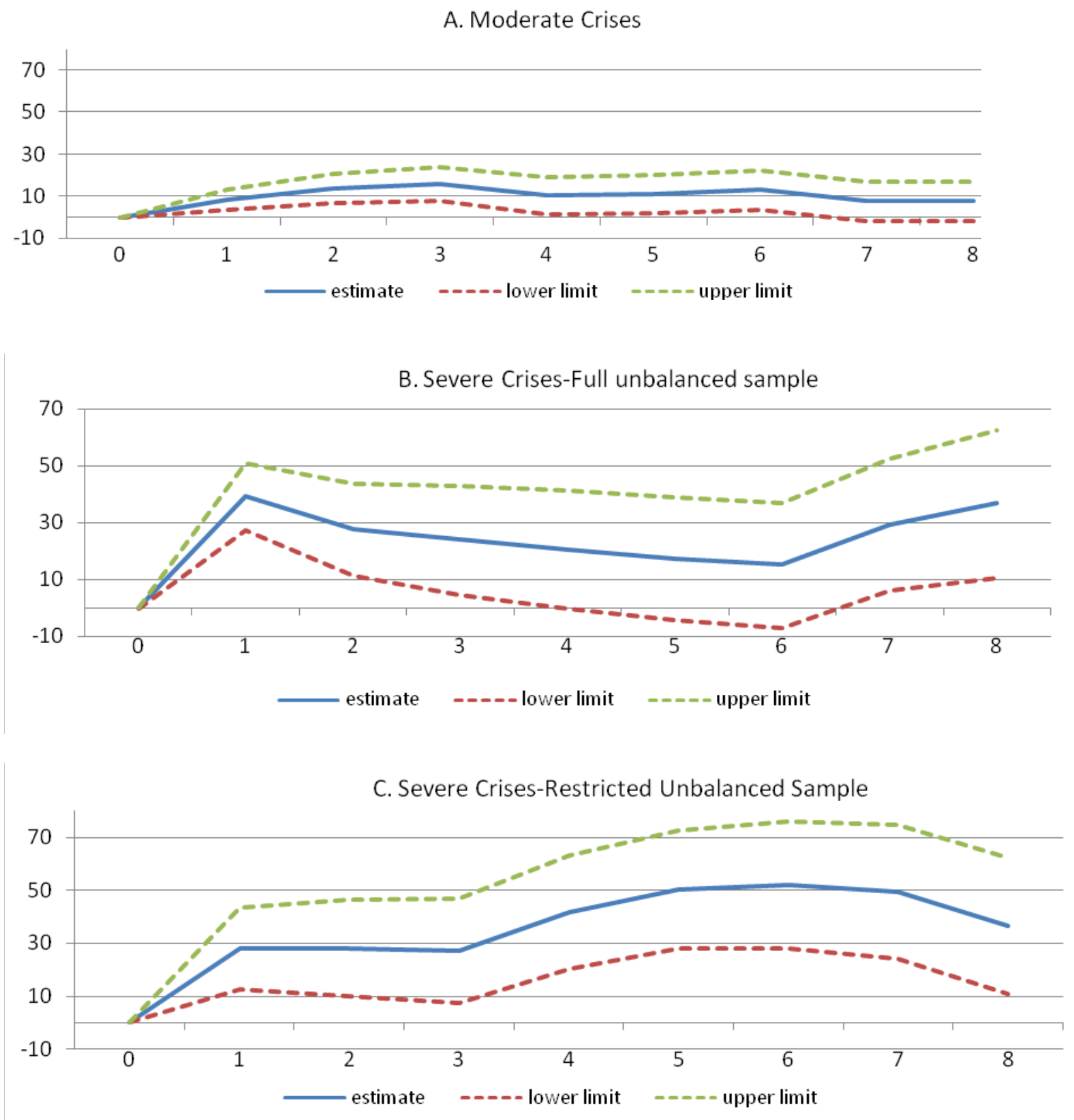

Note: dotted lines represent $90 \%$ confidence bands.

Figure 8. The effect of banking crises on debt-to-GDP ratio controlling for the initial debt ratio 
(\% points of GDP)

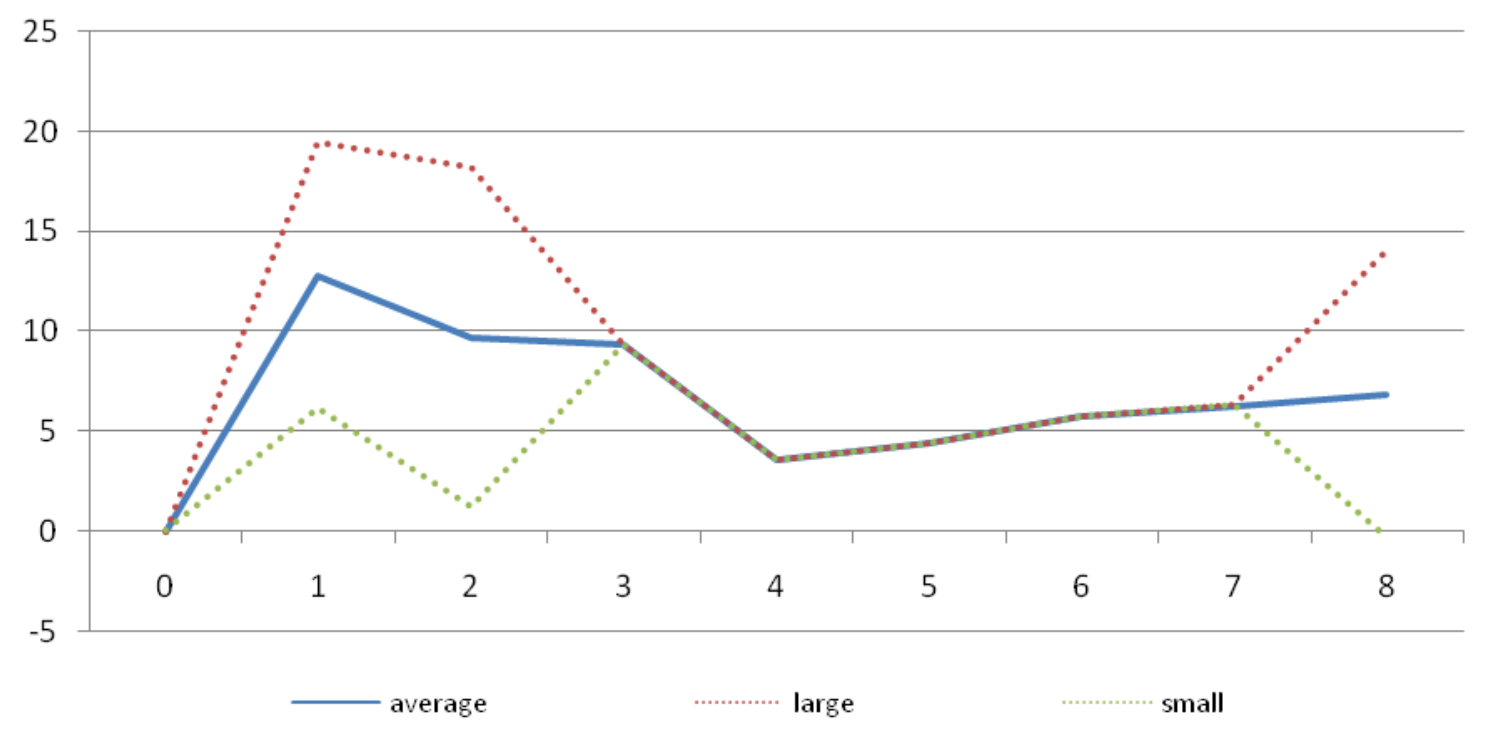

Note: Large and small identify the first and the third quartile of the initial debt-to-GDP ratio distribution. Dotted lines differ from the average response only when the interaction term is statistically significant.

Figure 9. The effect of banking crises on the debt-to-GDP ratio for different level of foreign debt ratio 
(\% points of GDP)
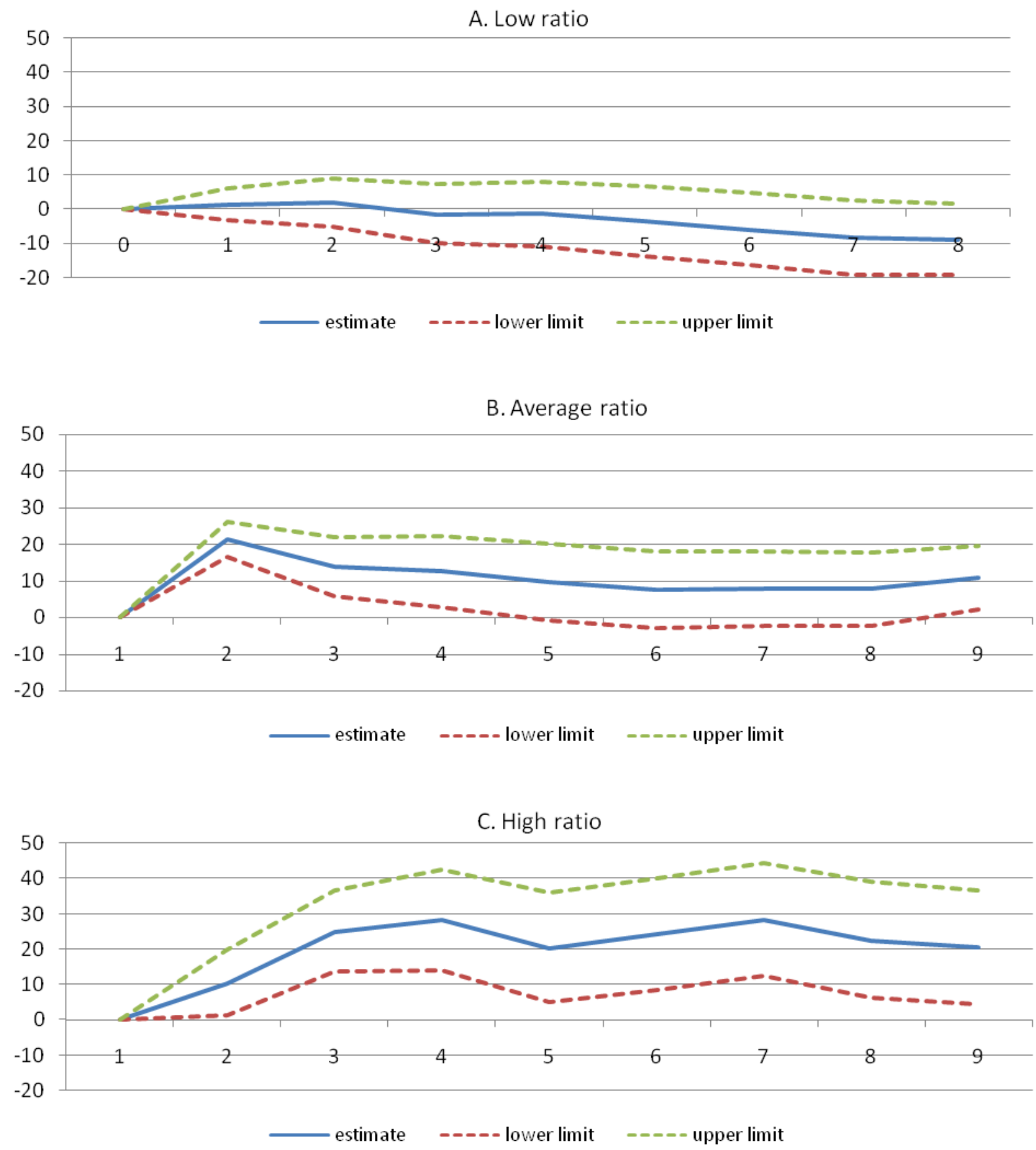

Note: dotted lines represent $90 \%$ confidence bands. Low ratio corresponds to a level of the foreign debt ratio lower than $34 \mathrm{pp} \mathrm{(} 1^{\text {st }}$ quartile of the distribution); Average ratio corresponds to a level of foreign debt ratio higher than 32 pp and lower than $75 \mathrm{pp}$; High ratio corresponds to a level of foreign debt ratio higher than $75 \mathrm{pp}$. $\left(3^{\text {rd }}\right.$ quartile of the distribution).

\section{ANNEX}

Figure A1. The effect of banking crises on debt service 
Interest expenditure over Total Revenue(\%)

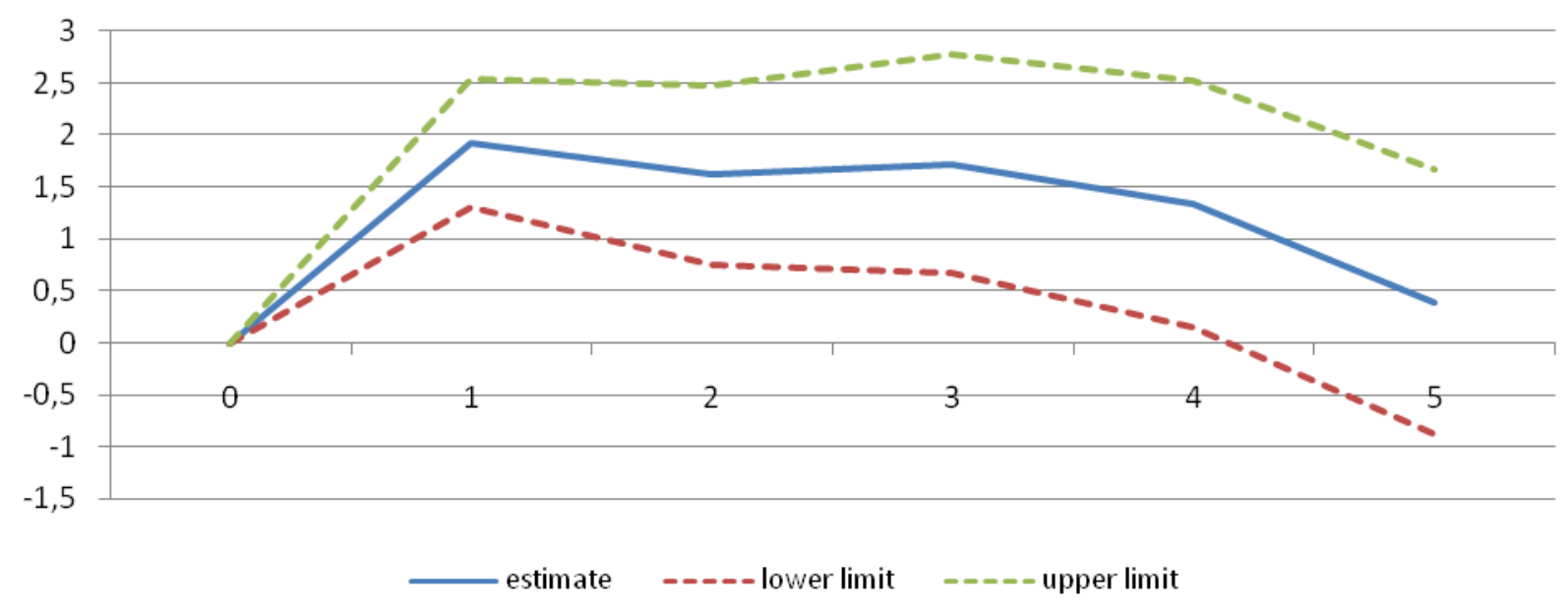

Interest expenditure over GDP (\%)

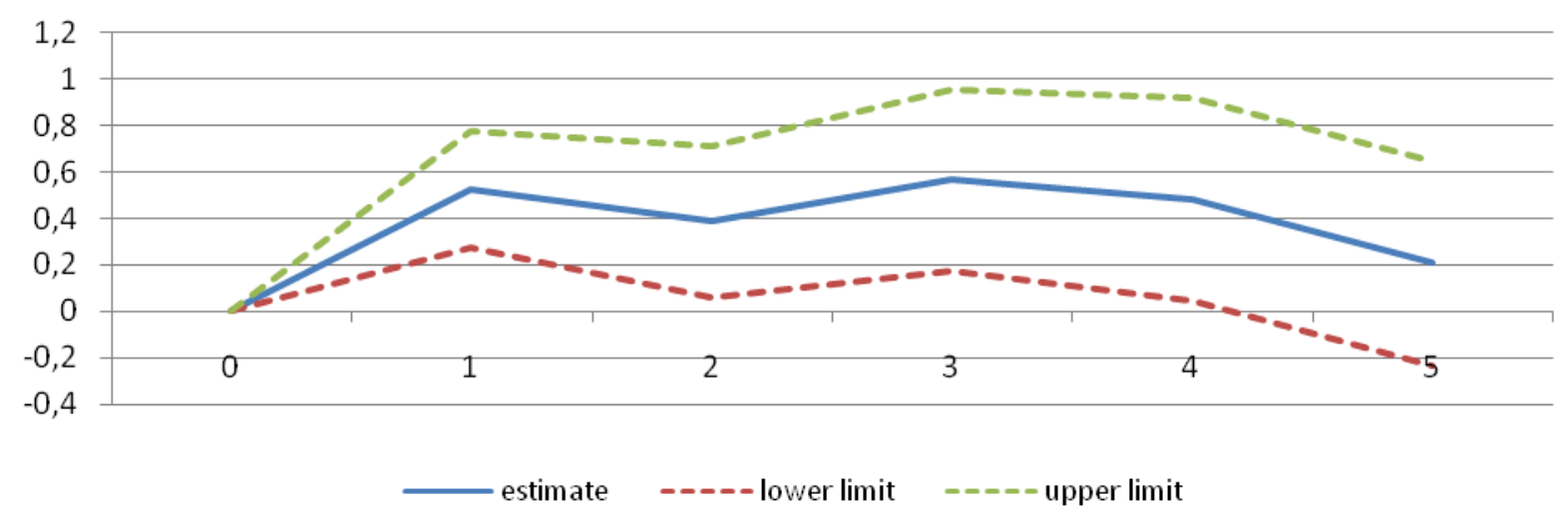

Note: dotted lines represent $90 \%$ confidence bands.

Table A1. Banking Crises Episodes

\begin{tabular}{|lc|lc|lc|}
\hline \multicolumn{1}{|c|}{ country } & time & \multicolumn{1}{c|}{ country } & time & country & time \\
\hline Albania & 1994 & Ecuador & 1998 & Norway & 1991 \\
Algeria & 1990 & Egypt, & 1980 & Panama & 1988 \\
\hline
\end{tabular}




\begin{tabular}{|c|c|c|c|c|c|}
\hline Argentina & 1980 & El Salvador & 1989 & Paraguay & 1995 \\
\hline Argentina & 1989 & Equatorial Guinea & 1983 & Peru & 1983 \\
\hline Argentina & 1995 & Eritrea & 1993 & Philippines & 1983 \\
\hline Argentina & 2001 & Estonia & 1992 & Philippines & 1997 \\
\hline Armenia & 1994 & Finland & 1991 & Poland & 1992 \\
\hline Azerbaijan & 1995 & Georgia & 1991 & Romania & 1990 \\
\hline Bangladesh & 1987 & Ghana & 1982 & Russian Federation & 1998 \\
\hline Belarus & 1995 & Guinea & 1985 & Sao Tome and Principe & 1992 \\
\hline Benin & 1988 & Guinea & 1993 & Senegal & 1988 \\
\hline Bolivia & 1986 & Guinea-Bissau & 1995 & Sierra Leone & 1990 \\
\hline Bolivia & 1994 & Guyana & 1993 & Slovak Rep. & 1998 \\
\hline Bosnia and Herzegovina & 1992 & Haiti & 1994 & Slovenia & 1992 \\
\hline Brazil & 1990 & Hungary & 1991 & Spain & 1977 \\
\hline Brazil & 1994 & India & 1993 & Sri Lanka & 1989 \\
\hline Bulgaria & 1996 & Indonesia & 1997 & Swaziland & 1995 \\
\hline Burkina Faso & 1990 & Israel & 1977 & Sweden & 1991 \\
\hline Burundi & 1994 & Jamaica & 1996 & Tanzania & 1987 \\
\hline Cameroon & 1987 & Japan & 1997 & Thailand & 1983 \\
\hline Cameroon & 1995 & Jordan & 1989 & Thailand & 1997 \\
\hline Cape Verde & 1993 & Kenya & 1985 & Togo & 1993 \\
\hline Central African Rep. & 1976 & Kenya & 1992 & Tunisia & 1991 \\
\hline Central African Rep. & 1995 & Korea, Rep. & 1997 & Turkey & 1982 \\
\hline Chad & 1983 & Kuwait & 1982 & Turkey & 2000 \\
\hline Chad & 1992 & Kyrgyz Rep. & 1995 & Uganda & 1994 \\
\hline Chile & 1976 & Latvia & 1995 & Ukraine & 1998 \\
\hline Chile & 1981 & Lebanon & 1990 & United Kingdom & 2007 \\
\hline China & 1998 & Liberia & 1991 & United States & 1988 \\
\hline Colombia & 1982 & Lithuania & 1995 & United States & 2007 \\
\hline Colombia & 1998 & Macedonia, FYR & 1993 & Uruguay & 1981 \\
\hline Congo, Dem. Rep. & 1983 & Madagascar & 1988 & Uruguay & 2002 \\
\hline Congo, Dem. Rep. & 1991 & Malaysia & 1997 & Venezuela, & 1994 \\
\hline Congo, Dem. Rep. & 1994 & Mali & 1987 & Vietnam & 1997 \\
\hline Congo, Rep. & 1992 & Mauritania & 1984 & Yemen, & 1996 \\
\hline Costa Rica & 1987 & Mexico & 1981 & Zambia & 1995 \\
\hline Costa Rica & 1994 & Mexico & 1994 & Zimbabwe & 1995 \\
\hline Cote d'Ivoire & 1988 & Morocco & 1980 & & \\
\hline Croatia & 1998 & Mozambique & 1987 & & \\
\hline Czech Rep. & 1996 & Nepal & 1988 & & \\
\hline Djibouti & 1991 & Nicaragua & 1990 & & \\
\hline Dominican, Rep. & 2003 & Nicaragua & 2000 & & \\
\hline Ecuador & 1982 & Niger & 1983 & & \\
\hline Ecuador & 1998 & Nigeria & 1991 & & \\
\hline
\end{tabular}

Source: Laeven and Valencia (2008a)

Table A2. Banking intervention policies

$\begin{array}{llccc}\text { Country } & \text { Time } & \text { Nationalization } & \begin{array}{c}\text { Blanket } \\ \text { guarantees }\end{array} & \begin{array}{c}\text { Liquidity } \\ \text { support }\end{array}\end{array}$




\begin{tabular}{|c|c|c|c|c|}
\hline Argentina & 1980 & 1 & 0 & 1 \\
\hline Argentina & 1989 & 0 & 0 & 1 \\
\hline Argentina & 1995 & 0 & 0 & 0 \\
\hline Argentina & 2001 & 1 & 0 & 1 \\
\hline Bolivia & 1994 & 0 & 0 & 1 \\
\hline Brazil & 1990 & 0 & 0 & 1 \\
\hline Brazil & 1994 & 0 & 0 & 1 \\
\hline Bulgaria & 1996 & 1 & 0 & 1 \\
\hline Chile & 1981 & 0 & 0 & 1 \\
\hline Colombia & 1982 & 1 & 0 & 1 \\
\hline Colombia & 1998 & 1 & 0 & 1 \\
\hline Cote d'Ivoire & 1988 & 0 & 0 & 1 \\
\hline Croatia & 1998 & 1 & 0 & 0 \\
\hline Czech Rep & 1996 & 0 & 0 & 0 \\
\hline Dominican Rep & 2003 & 0 & 0 & 1 \\
\hline Ecuador & 1998 & 1 & 1 & 1 \\
\hline Estonia & 1992 & 1 & 0 & 1 \\
\hline Finland & 1991 & 1 & 1 & 1 \\
\hline Ghana & 1982 & 0 & 0 & 0 \\
\hline Indonesia & 1997 & 1 & 1 & 1 \\
\hline Jamaica & 1996 & 1 & 1 & 1 \\
\hline Japan & 1997 & 1 & 1 & 0 \\
\hline Korea, Rep & 1997 & 1 & 1 & 1 \\
\hline Latvia & 1995 & 0 & 0 & 0 \\
\hline Lithuania & 1995 & 1 & 0 & 0 \\
\hline Malaysia & 1997 & 1 & 1 & 1 \\
\hline Mexico & 1994 & 1 & 1 & 1 \\
\hline Nicaragua & 1990 & 0 & 1 & 1 \\
\hline Norway & 1991 & 1 & 0 & 1 \\
\hline Paraguay & 1995 & 0 & 0 & 1 \\
\hline Philippines & 1997 & 0 & 0 & 0 \\
\hline Russian Federation & 1998 & 1 & 0 & 1 \\
\hline Sri Lanka & 1989 & 0 & 0 & 0 \\
\hline Sweden & 1991 & 1 & 1 & 1 \\
\hline Thailand & 1997 & 1 & 1 & 1 \\
\hline Turkey & 2000 & 1 & 1 & 1 \\
\hline Ukraine & 1998 & 0 & 0 & 1 \\
\hline Uruguay & 2002 & 1 & 1 & 0 \\
\hline Venezuela, & 1994 & 1 & 0 & 1 \\
\hline Vietnam & 1997 & 0 & 0 & 0 \\
\hline
\end{tabular}

Note: "1" refers to the adoption of the policy.

Source: Laeven and Valencia (2008b). 
Table A3. Estimates (1)

\begin{tabular}{|c|c|c|c|c|c|c|c|}
\hline$K$ & Baseline & Time FE & Time trend & $\begin{array}{c}\text { Country time } \\
\text { trend }\end{array}$ & Severe & Moderate & OECD \\
\hline 1 & $\begin{array}{c}13.226 \\
(4.72) * * *\end{array}$ & $\begin{array}{c}12.065 \\
(4.30)^{* * *}\end{array}$ & $\begin{array}{c}11.908 \\
(4.25)^{* * *}\end{array}$ & $\begin{array}{c}12.206 \\
(4.35)^{* * *}\end{array}$ & $\begin{array}{c}39.078 \\
(5.51)^{* * *}\end{array}$ & $\begin{array}{c}8.447 \\
(2.77)^{* * *}\end{array}$ & $\begin{array}{c}15.176 \\
(4.69)^{* * *}\end{array}$ \\
\hline 2 & $\begin{array}{c}15.893 \\
(4.13)^{* * *}\end{array}$ & $\begin{array}{c}13.657 \\
(3.58)^{* * *}\end{array}$ & $\begin{array}{c}13.291 \\
(3.48)^{* * *}\end{array}$ & $\begin{array}{c}13.869 \\
(3.61)^{* * *}\end{array}$ & $\begin{array}{c}27.563 \\
(2.81)^{* * *}\end{array}$ & $\begin{array}{c}13.694 \\
(3.27)^{* * *}\end{array}$ & $\begin{array}{c}17.372 \\
(3.98)^{* * *}\end{array}$ \\
\hline 4 & $\begin{array}{c}12.002 \\
(2.42)^{* *}\end{array}$ & $\begin{array}{l}7.351 \\
(1.53)\end{array}$ & $\begin{array}{c}7.832 \\
(1.61)^{*}\end{array}$ & $\begin{array}{c}8.602 \\
(1.76)^{*}\end{array}$ & $\begin{array}{l}20.470 \\
(1.62)^{*}\end{array}$ & $\begin{array}{c}10.410 \\
(1.93)^{* *}\end{array}$ & $\begin{array}{c}13.445 \\
(2.34)^{* *}\end{array}$ \\
\hline 5 & $\begin{array}{c}12.206 \\
(2.37)^{* *}\end{array}$ & $\begin{array}{l}6.937 \\
(1.4)\end{array}$ & $\begin{array}{c}7.872 \\
(1.58) *\end{array}$ & $\begin{array}{c}8.581 \\
(1.71)^{*}\end{array}$ & $\begin{array}{c}17.220 \\
(1.31)\end{array}$ & $\begin{array}{c}11.246 \\
(2.02)^{* *}\end{array}$ & $\begin{array}{c}13.706 \\
(2.30)^{* *}\end{array}$ \\
\hline 6 & $\begin{array}{c}13.441 \\
(2.57)^{* *}\end{array}$ & $\begin{array}{c}8.365 \\
(1.67)^{*}\end{array}$ & $\begin{array}{c}9.331 \\
(1.86)^{*}\end{array}$ & $\begin{array}{c}9.928 \\
(1.96)^{* *}\end{array}$ & $\begin{array}{l}15.012 \\
(1.12)\end{array}$ & $\begin{array}{c}13.102 \\
(2.31)^{* *}\end{array}$ & $\begin{array}{c}16.109 \\
(2.66)^{* * *}\end{array}$ \\
\hline 7 & $\begin{array}{c}10.747 \\
(2.05)^{* *}\end{array}$ & $\begin{array}{l}6.671 \\
(1.33)\end{array}$ & $\begin{array}{c}8.050 \\
(1.61)^{*}\end{array}$ & $\begin{array}{c}8.116 \\
(1.60)^{*}\end{array}$ & $\begin{array}{c}29.299 \\
(2.09)^{* *}\end{array}$ & $\begin{array}{r}7.684 \\
(1.36)\end{array}$ & $\begin{array}{c}13.233 \\
(2.12)^{* *}\end{array}$ \\
\hline 8 & $\begin{array}{c}10.910 \\
(2.08)^{* *}\end{array}$ & $\begin{array}{c}8.191 \\
(1.63)^{*}\end{array}$ & $\begin{array}{c}8.783 \\
(1.77)^{*}\end{array}$ & $\begin{array}{c}8.856 \\
(1.75)^{*}\end{array}$ & $\begin{array}{c}36.526 \\
(2.32)^{* *}\end{array}$ & $\begin{array}{l}7.681 \\
(1.38)\end{array}$ & $\begin{array}{c}13.499 \\
(2.14)^{* *}\end{array}$ \\
\hline
\end{tabular}

Note: t-statistics in parenthesis. $* * *, * * *$ denote significance at $1 \%, 5 \%$, and $10 \%$, respectively. 
Table A3. Estimates (2)

\begin{tabular}{|c|c|c|c|c|c|c|}
\hline$K$ & Severe & Moderate & $\begin{array}{c}\text { Small Foreign } \\
\text { debt }\end{array}$ & $\begin{array}{c}\text { Average Foreign } \\
\text { debt }\end{array}$ & $\begin{array}{c}\text { Large Foreign } \\
\text { Debt }\end{array}$ & Debt \\
\hline 1 & $\begin{array}{c}39.078 \\
(5.51)^{* * *}\end{array}$ & $\begin{array}{c}8.447 \\
(2.77)^{* * *}\end{array}$ & $\begin{array}{r}1.420 \\
(0.49)\end{array}$ & $\begin{array}{c}21.358 \\
(7.39)^{* * *}\end{array}$ & $\begin{array}{r}10.430 \\
(1.85)^{*}\end{array}$ & $\begin{array}{c}12.794 \\
(4.84)^{* * *}\end{array}$ \\
\hline 2 & $\begin{array}{c}27.563 \\
(2.81)^{* * *}\end{array}$ & $\begin{array}{c}13.694 \\
(3.27)^{* * *}\end{array}$ & $\begin{array}{l}2.000 \\
(0.47)\end{array}$ & $\begin{array}{c}13.793 \\
(2.83)^{* * *}\end{array}$ & $\begin{array}{c}25.029 \\
(3.35)^{* * *}\end{array}$ & $\begin{array}{c}9.706 \\
(2.99)^{* * *}\end{array}$ \\
\hline 3 & $\begin{array}{c}23.746 \\
(2.04)^{* *}\end{array}$ & $\begin{array}{c}15.795 \\
(3.19)^{* * *}\end{array}$ & $\begin{array}{l}-1.431 \\
(-0.27)\end{array}$ & $\begin{array}{c}12.493 \\
(2.11)^{* *}\end{array}$ & $\begin{array}{c}28.246 \\
(3.25)^{* * *}\end{array}$ & $\begin{array}{c}9.348 \\
(2.60)^{* * *}\end{array}$ \\
\hline 4 & $\begin{array}{l}20.470 \\
(1.62)^{*}\end{array}$ & $\begin{array}{l}10.410 \\
(1.93)^{* *}\end{array}$ & $\begin{array}{l}-1.334 \\
(-0.23)\end{array}$ & $\begin{array}{l}9.719 \\
(1.54)\end{array}$ & $\begin{array}{l}20.361 \\
(2.17)^{* *}\end{array}$ & $\begin{array}{l}3.575 \\
(0.96)\end{array}$ \\
\hline 5 & $\begin{array}{l}17.220 \\
(1.31)\end{array}$ & $\begin{array}{c}11.246 \\
(2.02)^{* *}\end{array}$ & $\begin{array}{l}-3.538 \\
(-0.57)\end{array}$ & $\begin{array}{l}7.503 \\
(1.19)\end{array}$ & $\begin{array}{c}24.237 \\
(2.52)^{* *}\end{array}$ & $\begin{array}{l}4.407 \\
(1.18)\end{array}$ \\
\hline 6 & $\begin{array}{l}15.012 \\
(1.12)\end{array}$ & $\begin{array}{l}13.102 \\
(2.31)^{* *}\end{array}$ & $\begin{array}{l}-5.846 \\
(-0.90)\end{array}$ & $\begin{array}{l}7.861 \\
(1.28)\end{array}$ & $\begin{array}{c}28.374 \\
(2.93)^{* * *}\end{array}$ & $\begin{array}{l}5.765 \\
(1.53)\end{array}$ \\
\hline 7 & $\begin{array}{l}29.299 \\
(2.09)^{* *}\end{array}$ & $\begin{array}{l}7.684 \\
(1.36)\end{array}$ & $\begin{array}{l}-8.216 \\
(-1.24)\end{array}$ & $\begin{array}{l}7.705 \\
(1.28)\end{array}$ & $\begin{array}{c}22.579 \\
(2.25)^{* *}\end{array}$ & $\begin{array}{c}6.309 \\
(1.65)^{*}\end{array}$ \\
\hline 8 & $\begin{array}{c}36.526 \\
(2.32)^{* *}\end{array}$ & $\begin{array}{l}7.681 \\
(1.38)\end{array}$ & $\begin{array}{l}-8.872 \\
(-1.40)\end{array}$ & $\begin{array}{c}10.820 \\
(2.08)^{* *}\end{array}$ & $\begin{array}{c}20.526 \\
(2.09)^{* *}\end{array}$ & $\begin{array}{c}6.883 \\
(1.79)^{*}\end{array}$ \\
\hline
\end{tabular}

Note: t-statistics in parenthesis. $* * *, * * *$ denote significance at $1 \%, 5 \%$, and $10 \%$, respectively. 